\title{
Treatment and effective utilization of greywater
}

\author{
Dhanu Radha Samayamanthula ${ }^{1} \cdot$ Chidambaram Sabarathinam $^{1} \cdot$ Harish Bhandary ${ }^{1}$
}

Received: 20 August 2018 / Accepted: 1 May 2019 / Published online: 13 May 2019

(c) The Author(s) 2019

\begin{abstract}
Sustainable management aims at the governance of natural resources to meet the needs of future generations. The limited resources of freshwater in arid regions have led to the development of alternative water management strategies. To meet the future challenges of water scarcity, an attempt has been made in this study to utilize treated greywater obtained by gravitygoverned filtration technique and disinfection for domestic usage. The study addresses the possibilities of groundwater recharge with the treated greywater. The method focuses on a gravity-governed flow through a column containing activated carbon, sand and gravel. The greywater used for the treatment contains a mixture of equal proportions of water collected from three different sources such as kitchen sink, shower and washing machine in Fahaheel, Salmiya and Farwaniya areas of Kuwait. The study concluded that for a volume of $1167 \mathrm{~cm}^{3}$ filtration media used, the designed column was $34 \%$ effective for first $1100 \mathrm{~mL}$ of greywater. Later, the column was regenerated by washing with distilled water and the regenerated column still proved to be effective with a removal efficiency of $26 \%$ for next $600 \mathrm{~mL}$ of greywater. The quality of the treated greywater was assessed in terms of physical, chemical and microbiological parameters as per the standard methods to check the suitability for domestic purposes. The results obtained were also compared with the groundwater quality of Kuwait group and Dammam aquifers, and it was inferred to be at par with their quality. The TDS of treated greywater has been reduced from 4910 to $1508 \mathrm{mg} / \mathrm{L}$, which is also lower than the TDS in groundwater of both the aquifers, and $\mathrm{pH}$ was reduced from 10.29 to 7.94 . The present study proved its efficiency equally to other existing methods, and the efficiency of removal for some of the analyzed parameters was measured as $23 \%, 95 \%, 52 \%, 88 \%, 100 \%$ and $100 \%$ for $\mathrm{pH}$, color, TDS, turbidity, total coliform and E. coli, respectively. Hence, the study is simple and cost-effective approach that can be adopted for the treatment and reused greywater for domestic and agriculture and also for recharging the aquifers to prevent saltwater intrusion along the coastal aquifers.
\end{abstract}

Keywords Greywater $\cdot$ Filtration $\cdot$ Disinfection $\cdot$ Regeneration $\cdot$ Aquifer

\section{Introduction}

Greywater is the wastewater usually generated from the kitchen sink, shower, laundry or washing machine, AC outlet, etc., which is sent through as a waste. This can be reused subsequently by a simple and cost-effective treatment technique. Kuwait is one among the top countries generating greywater followed by Uganda and Oman, but the utilization of treated greywater is not so effective.

The data in Table 1 signify that the generation of greywater in different countries ranges from 39 to $85 \%$. The data

Dhanu Radha Samayamanthula

vdhanuradha@kisr.edu.kw

1 Water Research Center, Kuwait Institute for Scientific Research, Shuwaikh, Kuwait bring out the fact that the consumption of domestic water varies from country to country and can be reduced up to $30 \%$ in Kuwait by using treated greywater. It has been observed that many countries focused on greywater treatment and reusing for several purposes like irrigation, firefighting, toilet flushing, etc. The above data infer that there is a great dependency on the quantum of greywater in near future, especially in Kenya, Syria, and Kuwait as the consumption of freshwater is not at par with the production of freshwater.

Kuwait being an arid region receives about $140 \mathrm{~mm}$ rainfall annually (Abusam 2008). This country has very limited freshwater and brackish water resources. The brackish water resource is mainly from Kuwait group and Dammam aquifer stretching east of the Arabian Peninsula and sloping toward the Arabian Gulf. Kuwait group is composed of layers of sediments and clastic rocks, and Dammam formation 
Table 1 Percentage of greywater generation and probable reduction of domestic water in different countries

\begin{tabular}{lllll}
\hline S. no. & Literature source & Country & $\begin{array}{l}\text { Generation of grey- } \\
\text { water }(\%)\end{array}$ & $\begin{array}{l}\text { Probable reduction of domestic water } \\
\text { consumption by using treated greywater } \\
(\%)\end{array}$ \\
\hline 1. & Abusam (2008) & Kuwait & 85 & 30 \\
2. & Revitt et al. (2011) & Australia & 50 & 29 \\
3. & Mourad et al. (2011) & Syria & 46 & 35 \\
4. & Kariuki (2011) & Kenya & $50-80$ & $33-54$ \\
5. & Al-Mashaqbeh et al. (2012) & Jordan & $50-80$ & - \\
6. & Al-Jarallah (2013) & Oman & 82 & - \\
7. & Abedin and Rakib (2013) & Dhaka & 67 & - \\
8. & Beler-Baykal (2015) & Istanbul & 75 & 25 \\
9. & Katukiza et al. (2014) & Uganda & 85 & - \\
10. & Juan et al. (2016) & Brazil & - & $29-35$ \\
11. & & Malaysia & 67 & 30 \\
12. & & South Korea & - & 26.5 \\
13. & & Los Angles & $13-65$ & - \\
14. & Redwood et al. (2013) & La Soukra, Tunisia & $55-80$ & - \\
\hline
\end{tabular}

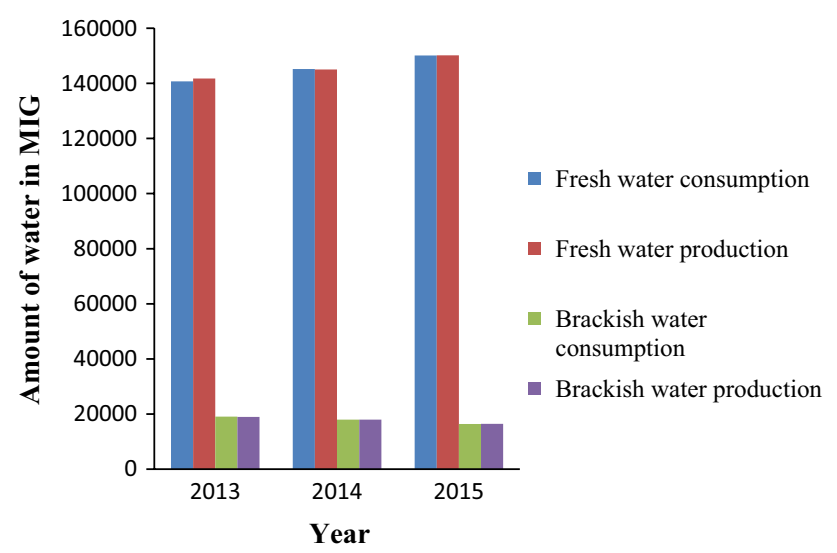

*MIG- Million Imperial Galloon

Fig. 1 Statistics on the Consumption and Production of Fresh Water and Brackish Water in Kuwait (Statistical Year Book (Water), Kuwait 2016). *MIG Million Imperial Galloon

contains layers predominantly of limestone saturated with water. In general, brackish water is used for irrigation, landscape, livestock watering and construction.

There is an increase in the consumption and production of freshwater every year (Fig. 1). The total consumption of freshwater and brackish water per day is around 473.2 MIG. The supply and demand for freshwater in Kuwait are chiefly dependent exclusively on desalination techniques like reverse osmosis (RO), electrodialysis and distillation. The distilled water obtained from desalination units of various plants in Kuwait is blended in a specific ratio with brackish groundwater extracted from different wells like Sulaibiya, Shigaya, Al-Wafra, Um-Gudair and
Al-Atraaf (Statistical Year Book 2016) leading to increase in the consumption of brackish groundwater. The process of desalination results in the emission of greenhouse gases, salt or brine disposal obtained either by distillation or by RO which may deplete the oxygen in the water and affect the marine life (Terry 2018), thereby enriching the concentration of metals and other organic constituents. Though the freshwater produced by the above methods meets the demands, it results in consumption of brackish water, high energy and even leads to environmental pollution. Hence, for sustainable development it is essential to think about the alternative sources for fulfilling the water needs. The demand for alternative sources has also been stressed by considering the importance of greywater use in Kuwait (Abusam 2008; Al-Jarallah 2013; Alaziz and Al-Saqer 2014). Few studies even supported the artificial recharge of aquifers using treated wastewater (Leas et al. 2013; Packialakshmi et al. 2015). There are many reported methods for the greywater treatment studies (Table 5), but the cost-effectiveness and the quantity of the treatment materials used for the proportion of treated greywater are more significant for considering the applicability of the method.

Therefore, to replenish the declined water resources for future sustainability a low-cost method with a unique household technique was attempted for greywater treatment which can subsequently reduce the groundwater extraction. Hence, the main objective of the present study is to develop an effective treatment of greywater using gravity-governed filtration technique and to determine its suitability for groundwater recharge by comparing the treated greywater quality with that of Kuwait group and Dammam aquifers. 


\section{Materials and methodology}

\section{Materials}

The treatment for the greywater was based on gravity-governed slow sand filtration and disinfection using bleaching powder. The filtration was done through a column packed with filtration media. The selection of materials used in the column was purely based on the earlier removal studies (Huisman and Wood 2005; MWRI-GOSS 2009; Bagundol et al. 2013), such as sand and gravel remove microorganisms and suspended solids; sieve removes floating matter; and activated carbon removes organic pollutants, color and odor. The size and volume of the materials used in the column are presented in Table 2.

\section{Experimental design}

The treatment of greywater is represented in a schematic diagram (Fig. 2).

\section{Method}

One liter of greywater from each source, kitchen sink, shower and the washing machine, was collected separately and blended. Three liters of the greywater was passed through the column of height $25 \mathrm{~cm}$ and radius $4.5 \mathrm{~cm}$, containing the following layers from bottom to top, viz. cotton, activated carbon, fine and coarse sand, small and big gravel.

Five hundred milliliters of greywater was allowed to flow through the column batch-wise, at the rate of $6.5 \mathrm{~mL} / \mathrm{min}$, and collected. Once the filtration process reached the saturation point, the column was regenerated by passing $500 \mathrm{~mL}$ of distilled water twice at the rate of $4.5 \mathrm{~mL}$ and $6.0 \mathrm{~mL} /$ min without removing the materials and the filtration was continued. The column was replaced with the fresh materials when it was completely clogged. The filtered greywater was subjected to disinfection using bleaching powder $0.05 \mathrm{~g} / \mathrm{L}$.
The physical, chemical and microbiological analysis were carried out in the Water Research Center laboratory, KISR for greywater by adopting standard methods for the examination of water and wastewater SMEWW (Rice 2017) for $\mathrm{pH}, \mathrm{EC}$, TDS, alkalinity, turbidity, total coliform, E. coli and anions $\mathrm{F}^{-}, \mathrm{Cl}^{-}, \mathrm{NO}_{3}{ }^{-}, \mathrm{SO}_{4}{ }^{2-}, \mathrm{PO}_{4}{ }^{3-}$. The major cations $\mathrm{NH}_{4}^{+}, \mathrm{K}^{+}, \mathrm{Na}^{+}, \mathrm{Ca}^{2+}$ and $\mathrm{Mg}^{2+}$ were analyzed in ion chromatography using American Standard Test Method D691917 (ASTM 2017) and trace metals in inductively coupled plasma-optical emission spectrometry by USEPA 200.7 method (U.S. EPA 1994).

The small-scale treatment setup was arranged at each location Fahaheel, Salmiya and Farwaniya in Kuwait and the sampling process was carried out on a daily basis for a week continuously at all the three locations and the column was replaced three times in all these locations.

\section{Results and discussion}

\section{Untreated and treated greywater characteristics}

\section{Untreated greywater}

Greywater mainly consists of organic as well as inorganic pollutants. Few important parameters were measured before the treatment. $\mathrm{pH}$ plays a vital role to determine the acidic or basic nature of the water. The $\mathrm{pH}$ of untreated greywater of all the three locations had an average of 10.29. Electrical conductivity (EC) is one of the significant parameters that determine the total dissolved solids (TDS). The average EC and TDS of untreated greywater were $4910 \mu \mathrm{S} / \mathrm{cm}$ and $3140 \mathrm{mg} / \mathrm{L}$, respectively. Turbidity, a part of suspended matter, helps to know the amount of suspended solids though both are not directly proportional. It was recorded as 199 NTU. In Salmiya, the untreated greywater had a higher $\mathrm{pH}$, but the EC and TDS were lower than the Fahaheel and Farwaniya areas. The microbiological parameters, total coliform and $E$. coli, were more than $2419.6 \mathrm{MPN} / 100 \mathrm{~mL}$.
Table 2 Measurements of materials used in the column for filtration

\begin{tabular}{lllll}
\hline $\begin{array}{l}\text { S. no. } \\
\text { Filtering media (bottom } \\
\text { to top) }\end{array}$ & $\begin{array}{l}\text { Size of the material } \\
\text { in mm }\end{array}$ & $\begin{array}{l}\text { The volume of the material } \\
\text { used in cubic cm }\end{array}$ & $\begin{array}{l}\text { \% Volume } \\
\text { of the mate- } \\
\text { rial }\end{array}$ \\
\hline 1. & Cotton & - & - & - \\
2. & Activated carbon & $<1.0$ & 85 & 7.28 \\
3. & Fine sand & $<0.5$ & 191 & 16.37 \\
4. & Coarse sand & $1.0 / 0.5$ & 191 & 16.37 \\
5. & Small gravel & $4.0 / 2.0$ & 318 & 27.25 \\
6. & Big gravel & $4.0 / 12.0$ & 382 & 32.73 \\
7. & Sieve & 0.5 & - & - \\
\hline
\end{tabular}




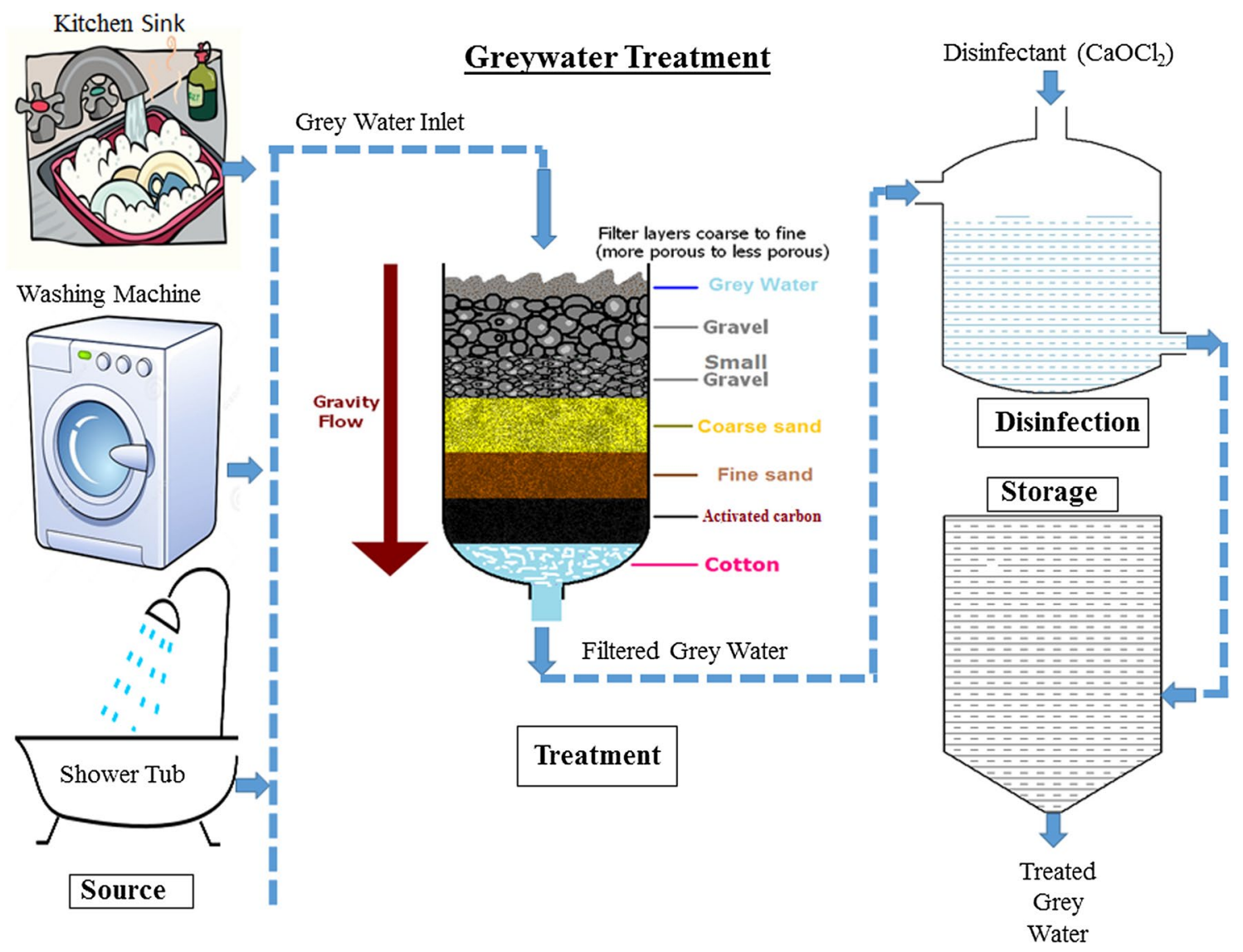

Fig. 2 Schematic diagram for the treatment of greywater

\section{Treated greywater}

The blackish brown color of the greywater turns nearly colorless after the treatment. The whole analysis results of treated greywater are presented in Table 3 . In the present study, the treated greywater $\mathrm{pH}$ varies in all the three areas but found to be higher in Salmiya. Its average value has been reduced significantly from 10.29 to 7.94 . EC of the treated greywater ranged from 1298 to $3682 \mu \mathrm{S} / \mathrm{cm}$, and the average was $2325 \mu \mathrm{S} / \mathrm{cm}$, which is usually lower because the raw water used in the houses for domestic purposes is desalinated. Turbidity reduces because of the reduction of suspended and dissolved solids. Few research studies reported that the sand filtration using activated carbon is a superior method and reduces mainly $\mathrm{pH}$, TDS, turbidity and COD when the wastewater is passed through it (Prasad et al. 2006; Khalaphallah 2012; Saad et al. 2016). The same has been observed in the present study using the above technique. The nutrients ammonium, nitrate, potassium and phosphate were found to be slightly higher in Farwaniya. Sodium ion, one of the major ions, is lower in Salmiya compared to the other two areas. Since the household water itself is desalinated, the metals are present in traces. A further decrease in concentration of metals was noticed in the treated greywater due to a decrease in the rate of flow and presence of active sites on the surface of sand and activated carbon (Mohan and Chander 2001; Barkouch et al. 2018). The greater is the surface area on the filtering media, the larger is the adsorption of trace metals.

The microbiological parameters such as total coliform (TC) and Escherichia coli (E. coli) were analyzed using Colilert-18 media. The disinfection of the filtered greywater was carried out using bleaching powder in Fahaheel area, whereas trichloroisocyanuric acid was used in Salmiya and Farwaniya areas. It was noticed that total coliform and E. coli were present in Salmiya and Farwaniya areas. The sample analysis results of total coliform in Salmiya and Farwaniya were recorded as 196 and $56 \mathrm{MPN} / 100 \mathrm{~mL}$ and E. coli as 57.6 and 14.5 , respectively. The same sample of those two areas was disinfected using bleaching powder and analyzed for total coliform and E. coli which were found to be less than 1.0 MPN $/ \mathrm{mL}$.

The sand filtration techniques are effective in reducing the microbes (Yogafanny et al. 2014), but the complete removal was observed only by disinfection with bleaching powder. Bleaching powder (calcium hypochlorite) when dissolved in 


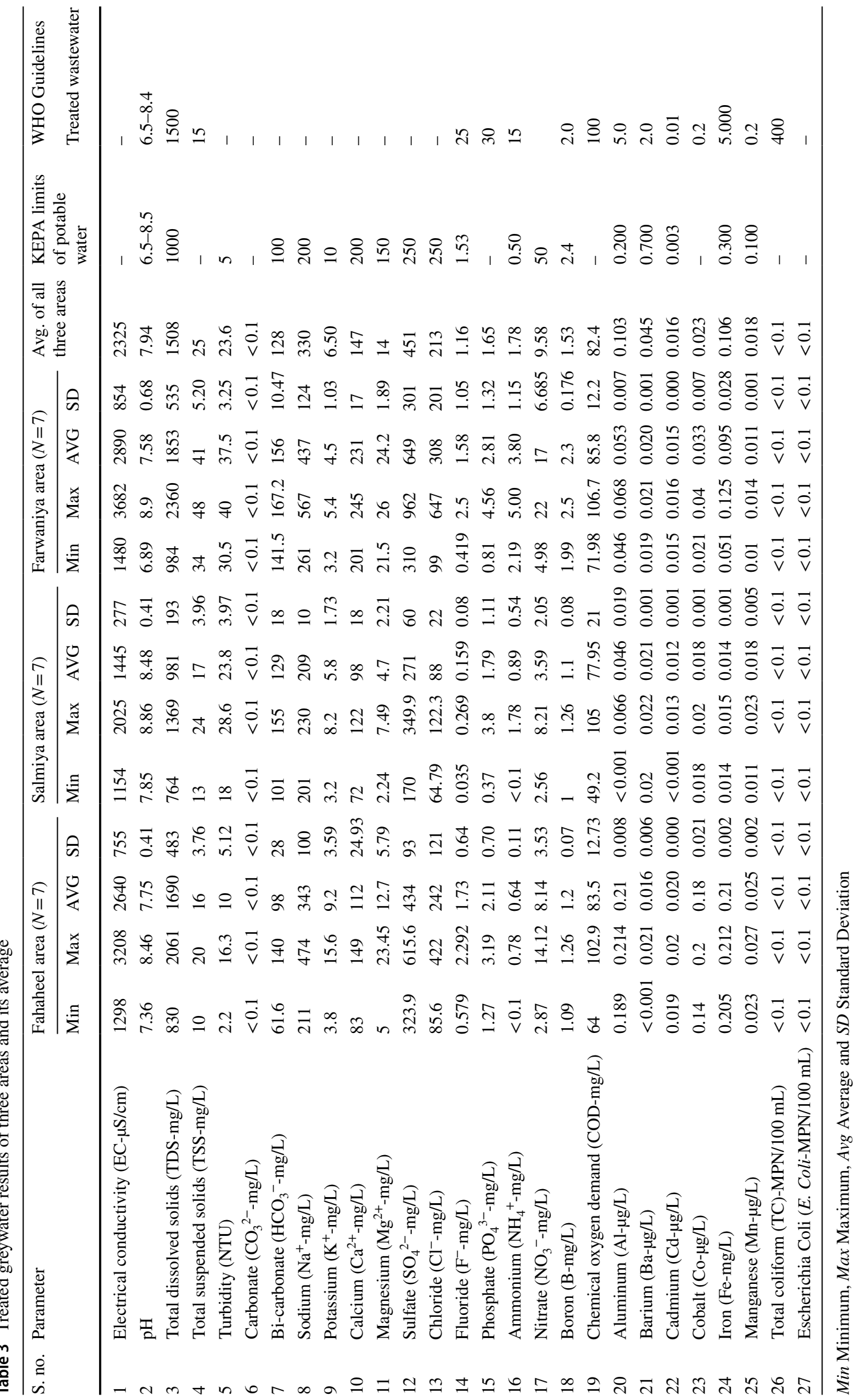


water reacts to form hypochlorous acid. Since the $\mathrm{pH}$ of the filtered greywater is alkaline, hypochlorous acid dissociates into hypochlorite ion and undergoes the oxidation reaction, which kills the microorganisms (EPA 2011) and simultaneously reduces the $\mathrm{pH}$ of the treated greywater.

The characteristics of treated greywater differed from each area since the detergents, soaps and dishwashing liquid used are not the same. The average results from three selected areas Fahaheel, Salmiya and Farwaniya of the treated greywater are within the WHO guidelines (WHO 2006).

For a few parameters, the treated greywater values are higher than the groundwater values, but still within the potable limits of Kuwait Environmental Protection Agency (KEPA 2017) except for phosphate and ammonium. Though the groundwater is used for various purposes, the basic utility of the water extracted from the aquifers is to serve the domestic needs but not for drinking purpose. Hence, this treated greywater is compared with groundwater.

\section{Mechanism of the adsorption process in the sand filtration}

The sand acts as a good filtration medium. The sand filtration is a combination of physical, chemical and biological process as it removes turbidity, organic matter and microorganisms (Verma et al. 2017; Lechevallier and Au 2004). Coarse particles help to remove suspended solids, whereas fine particles remove ions by adsorption and ion exchange mechanism (Chidambaram et al. 2003). Further, the removal process is more effective with the increase in surface area.

Pure carbon is hydrophobic in nature, but the oxygen associated with the carbon surface increases the hydrophilic nature of the activated carbon. The nature of adsorption of various compounds from water by activated carbon reveals the fact that granular activated carbon has different functional groups which have the capacity to adsorb negative ions, positive ions and trace metals (Ghoneim et al. 2014). The mechanism of adsorption of compounds present in the greywater is inferred to be removed by surface interactions between the compounds in water and activated carbon through van der Waal forces of attraction, among which induced dipole-dipole interactions is observed to be more effective (Nowicki and Nowicki 2016). Activated carbons are hydrophobic and contain small amounts of neutral $\mathrm{C}-\mathrm{O}$ surface groups. The chemisorbed oxygen $\mathrm{C}-\mathrm{O}$ in activated carbon is present as $\mathrm{CO}_{2}$ and $\mathrm{CO} . \mathrm{CO}_{2}$ is acidic and makes the surface hydrophilic and polar, which enhances the adsorption of polar chemical or ionic species, whereas $\mathrm{CO}$ is neutral and makes the surface hydrophobic and nonpolar. Hydrophilic compounds interact with water by polar-polar interactions, which cause adsorption of the ionized micropollutants on the surface of the activated carbon due to electrostatic interactions and sorbent-sorbent interactions. Further, it is also inferred by researchers that the optimal dosage of activated carbon increases the efficiency of treatment (Nam et al. 2014).

There exists an electrostatic attractive or repulsive interaction between the metal cations present in the greywater and the carbon-oxygen surface groups on the active carbon surface. The positive electro-charge of activated carbon attracts negatively charged organic anions on the surface, which is observed by a decrease in the $\mathrm{pH}$ of treated greywater. At high $\mathrm{pH}$, adsorption rate has increased which might be due to competition between $\mathrm{H}^{+}$ions and $\mathrm{M}^{+}$ions (Fernando et al. 2009). Adsorption of organic compounds is chiefly due to dispersive interactions, electron donor-acceptor interactions and electrostatic attractive or repulsive interactions between the charged carbon surface and the ions in the water (Bansal and Goyal 2005).

The micropores in the activated carbon also play a vital role in the adsorption to take place. The higher the degree of microporosity, the greater is the adsorption capacity on the surface. The relatively large adsorption capacities of activated carbons are attributed to their external surface areas, their large pore volumes and a high degree of surface reactivity (Gonzalez-Serrano et al. 2004). It is also noted that activated carbon has removed the color of the greywater which is identified by the colorless nature of the treated greywater. It is also to be noted that if the time of contact between the flow of water and the materials present in the column increases, the efficiency in removal also increases (Silva 2000).

\section{Comparison of treated water quality and treatment techniques with the literature}

The characteristics of greywater and its treatment of the present study are compared with the previous studies in Table 4 . The treated greywater quality in terms of $\mathrm{pH}, \mathrm{COD}$, nutrients, metals and microbial was relatively equivalent to other reported methods. There are several methods available for the treatment of greywater, but only a few methods were based on sand filtration and chlorinate ion. The present method adopted was similar to Gual et al. (2008), but it was modified by using a small amount of activated carbon. Further, there is effective removal of color, dissolved solids, ions, metals, microbes and turbidity in the treated water. In addition, this method is also advantageous by considering that the volume of the material used for treatment is lesser compared to the volume of treated greywater.

The volume of the materials used for the total treatment of $21 \mathrm{~L}$ of greywater was $3.5 \times 10^{-3} \mathrm{~m}^{3}$, with a specific volume of each material mentioned in Table 2. Further, the regeneration of the materials in the column was also proved to be effective, which states that there was a further increase 
Table 4 Comparison of physical, chemical and microbiological quality of treated greywater with other reported studies (The values are in mg/L except for $\mathrm{pH}$ )

\begin{tabular}{|c|c|c|c|c|c|c|c|}
\hline \multirow[t]{2}{*}{ Parameters } & $\begin{array}{l}\text { Finley et al. } \\
(2008)\end{array}$ & $\begin{array}{l}\text { Christova-Boal } \\
\text { et al. (1996) }\end{array}$ & Friedler (2004) & $\begin{array}{l}\text { Surendran } \\
\text { and Wheatley } \\
(1998)\end{array}$ & $\begin{array}{l}\text { Saroj and Sane } \\
\text { (2011) }\end{array}$ & $\begin{array}{l}\text { Kuwait (present } \\
\text { study) }\end{array}$ & WHO Guidelines \\
\hline & $\begin{array}{l}\text { Shower and } \\
\text { washing } \\
\text { machine }\end{array}$ & $\begin{array}{l}\text { Bathroom and } \\
\text { laundry }\end{array}$ & $\begin{array}{l}\text { Shower and } \\
\text { laundry }\end{array}$ & $\begin{array}{l}\text { Shower and } \\
\text { laundry }\end{array}$ & $\begin{array}{l}\text { Bathroom, } \\
\text { basin }\end{array}$ & $\begin{array}{l}\text { Kitchen, shower } \\
\text { and washing } \\
\text { machine }\end{array}$ & $\begin{array}{l}\text { Treated waste- } \\
\text { water }\end{array}$ \\
\hline $\mathrm{pH}$ & $6.7-7.9$ & $6.4-10.0$ & $7.4-7.5$ & $7.6-8.1$ & 7.43 & 7.94 & $6.5-8.4$ \\
\hline Total solids & $330-633$ & - & 1091-2021 & $631-658$ & 204 & 1533 & 1515 \\
\hline Sodium & $18-27$ & $7.4-480$ & $151-530$ & - & 17.11 & 330 & - \\
\hline Potassium & $0.6-4.4$ & - & - & - & 1.98 & 6.5 & - \\
\hline Calcium & $28-44$ & $3.5-12$ & - & - & 0 & 147 & \\
\hline Magnesium & $8.0-10.1$ & $1.1-2.9$ & - & - & 0 & 14 & - \\
\hline Phosphorus as $\mathrm{P}$ & $0.24-1.21$ & $0.062-42$ & $3.3-55.0$ & $1.63-101$ & 0 & 0.73 & 10.2 \\
\hline $\mathrm{NH}_{4}-\mathrm{Nitrogen}$ & $4.1-5.1$ & $<0.1-15$ & $1.2-4.9$ & $1.56-10.7$ & 0.21 & 1.38 & 15 \\
\hline Nitrate-Nitrogen & - & - & - & - & 0.21 & 2.16 & - \\
\hline COD & $161-348$ & - & 319-996 & $424-725$ & 58 & 82.4 & 100 \\
\hline Aluminum & ND & $<1.0-21$ & - & - & - & $0.103(\mu \mathrm{g} / \mathrm{L})$ & 5 \\
\hline Cadmium & ND & $<0.001$ & - & $<0.001$ & - & $0.016(\mu \mathrm{g} / \mathrm{L})$ & 0.15 \\
\hline Cobalt & ND & - & - & - & - & $0.023(\mu \mathrm{g} / \mathrm{L})$ & 0.2 \\
\hline Iron & $0.08-0.45$ & $0.29-1.1$ & - & - & - & 0.106 & 5.0 \\
\hline Manganese & ND & - & - & - & - & $0.018(\mu \mathrm{g} / \mathrm{L})$ & 0.2 \\
\hline Chromium & ND & - & - & $0.11-0.32$ & - & - & 0.15 \\
\hline Copper & ND & $<0.05-0.27$ & - & - & - & - & 0.2 \\
\hline Molybdenum & ND & - & - & - & - & - & - \\
\hline Sulfur & $3.3-8.0$ & $1.2-40$ & - & $0.003-0.03$ & - & - & 0.1 \\
\hline Zinc & $0.01-0.42$ & $0.09-6.3$ & - & $0.059-0.31$ & - & - & 2.0 \\
\hline $\begin{array}{l}\text { Total Coliform } \\
\text { (MPN/100 mL) }\end{array}$ & - & - & - & - & - & $<1.0$ & 400 \\
\hline $\begin{array}{l}\text { Fecal Coliform } \\
(\mathrm{MPN} / \mathrm{mL})\end{array}$ & $\begin{array}{r}2.2 \times 10^{4}- \\
1.4 \times 10^{6}\end{array}$ & $110-3.3 \times 10^{3}$ & $4 \times 10^{6}$ & $600-728$ & - & - & - \\
\hline $\begin{array}{l}\text { Escherichia coli } \\
(\mathrm{MPN} / \mathrm{mL})\end{array}$ & - & - & - & - & - & $<1.0$ & - \\
\hline
\end{tabular}

in the volume of treated water for the given volume of material. The amount of material used for the treatment of $11 \mathrm{of}$ greywater was estimated as $0.166 \times 10^{-3} \mathrm{~m}^{3}$ of which the activated carbon forms $7 \%$ of the material involved, i.e., about $11.62 \times 10^{-6} \mathrm{~m}^{3}$ for 11 . Considering the cost of activated carbon and the other materials used, 11 of treated water costs about $0.0011 \mathrm{KWD}$. This signifies the costeffectiveness of the present treatment method and also the fact that the treated water characteristics were below the guidelines.

The efficiency of removal in the present study was calculated by using the formula (Untreated greywater-Treated greywater $\div$ Untreated greywater $\times 100$ ) and is presented in Table 5. It was observed that the efficiency was equivalent to other reported methods with the low capital and maintenance cost. From the data in Table 5, it is inferred that other methods involve high capital and maintenance cost compared to the present study.

\section{The effectiveness of the column}

Treatment effectiveness of the column was verified by collecting the greywater sample from the washing machine due to its high conductivity. At first, $500 \mathrm{~mL}$ of greywater collected from washing machine alone was passed through the column and the first drop was noticed at $3.32 \mathrm{~min}$. Subsequently, it was sampled for every $100 \mathrm{~mL}$ and EC was measured. The rate of flow during the first batch was $6.5 \mathrm{~mL} / \mathrm{min}$, and later the rate of flow reduced to $3.0 \mathrm{~mL} /$ min. The variation in the rate of flow in the gravity-governed system may be due to various reasons: (1) head pressure, (2) permeability of the medium (grain size), and (3) heterogeneity of the medium. During this process, as the initial head pressure decreases, the rate of flow through the medium also decreases, resulting in more contact time with the medium, thereby enhancing the removal efficiency. 


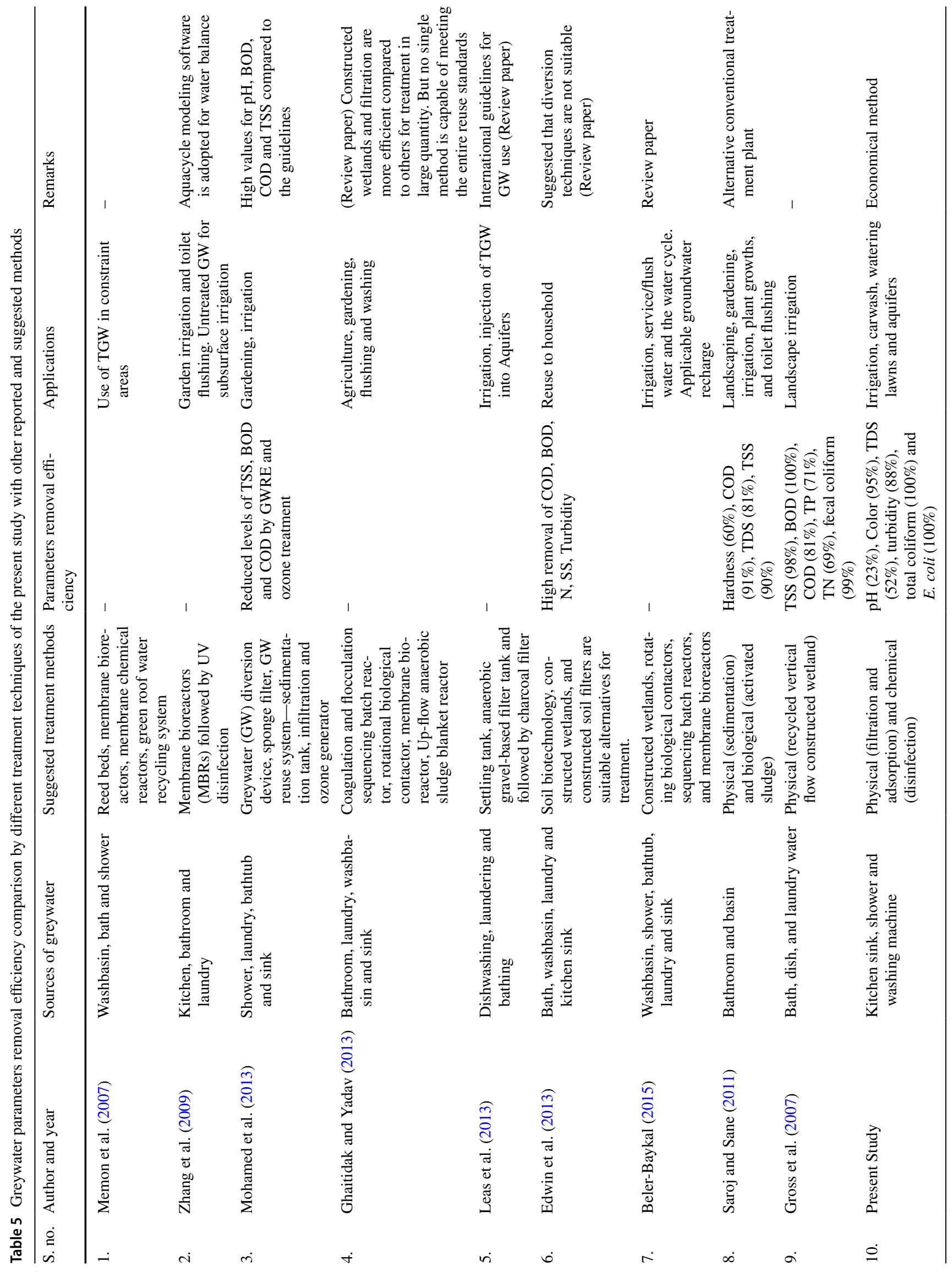


Initially, the surface sites are free to get adsorbed and inferred that the rate of removal was higher during the initiation of the experiment. From Fig. 3, it was observed that the column was effective for $1100 \mathrm{~mL}$ of greywater which is around $34 \%$ efficient in removal. The regeneration of the column was attempted by cleaning with distilled water and the effectiveness of the regenerated column had an efficiency of $26 \%$ for $600 \mathrm{~mL}$ (Fig. 4).

\section{Comparison of treated greywater with the groundwater of aquifers}

The comparison was made between the parameters observed in the groundwater for the respective aquifers of the study area and treated greywater. The available groundwater in Kuwait is more or less equivalent to brackish water. The average of the reported values of Dammam and Kuwait group aquifers was considered for comparison of the quality. From Table 6 and Fig. 5, it inferred that the EC, TDS, $\mathrm{Mg}^{2+}$, $\mathrm{NO}_{3}{ }^{-}, \mathrm{Cl}^{-}, \mathrm{K}^{+}, \mathrm{Na}^{+}$were very low in treated greywater than that of the groundwater in Dammam and Kuwait group aquifers. The $\mathrm{pH}$ of treated greywater in the present study was slightly higher than the groundwater, but lower than the
WHO limits and the reported literature methods. Similarly, the $\mathrm{Ca}^{2+}, \mathrm{SO}_{4}{ }^{2-}, \mathrm{NO}_{3}{ }^{-}$were lesser in greywater, but the $\mathrm{HCO}_{3}{ }^{-}$was almost of the same value to that of Dammam and Kuwait aquifers. The ionic concentration in Dammam group aquifer is less than Kuwait group aquifer, whereas the treated greywater was observed to have lesser concentration than the Dammam aquifer. Therefore, the treated greywater obtained by the present method was inferred to be suitable for recharging the aquifers.

\section{Conclusion}

The study has led to the development of domestic greywater treatment system by adopting the gravity filtration technique. The current study was attempted for the greywater with an $\mathrm{EC}$ of $4910 \mu \mathrm{S} / \mathrm{cm}$. The present study has inferred that a volume of $1100 \mathrm{~mL}$ of treated greywater is produced from $1167 \mathrm{~cm}^{3}$ of filtration medium. The study also reveals that the efficiency of removal varies with flow rate and proves to be effective even after regeneration.

The treated greywater has total dissolved solids of $1508 \mathrm{mg} / \mathrm{L}$, which is lower than both the aquifers. $\mathrm{pH}$ of the
Fig. 3 Verification of column effectiveness

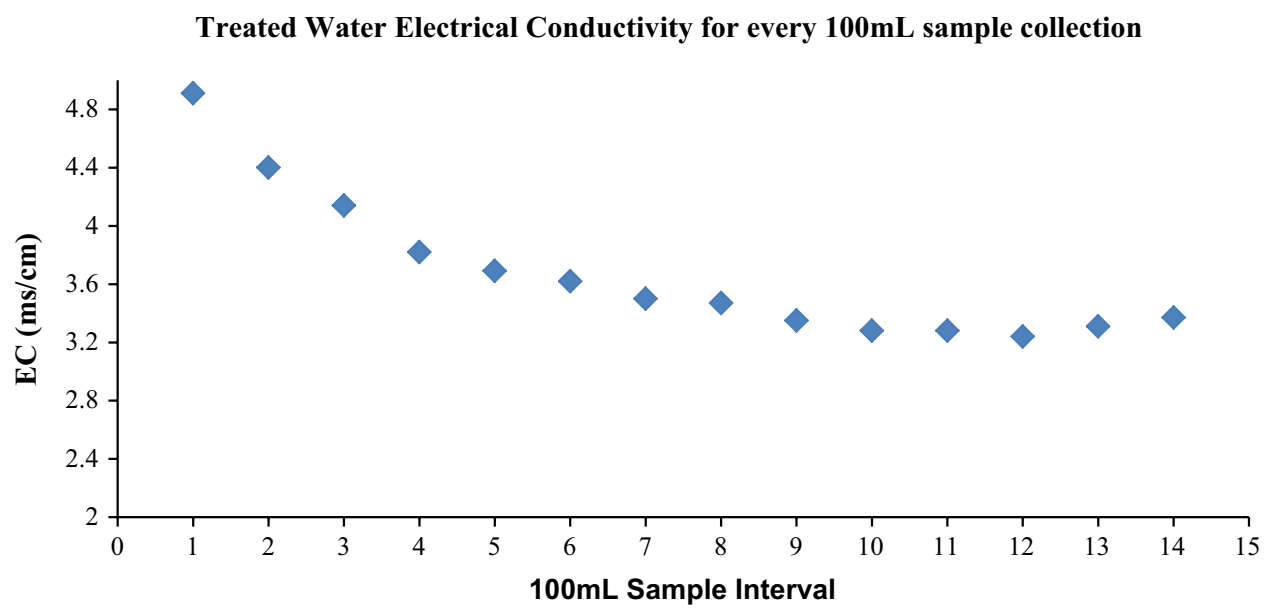

Fig. 4 Regenerated column effectiveness

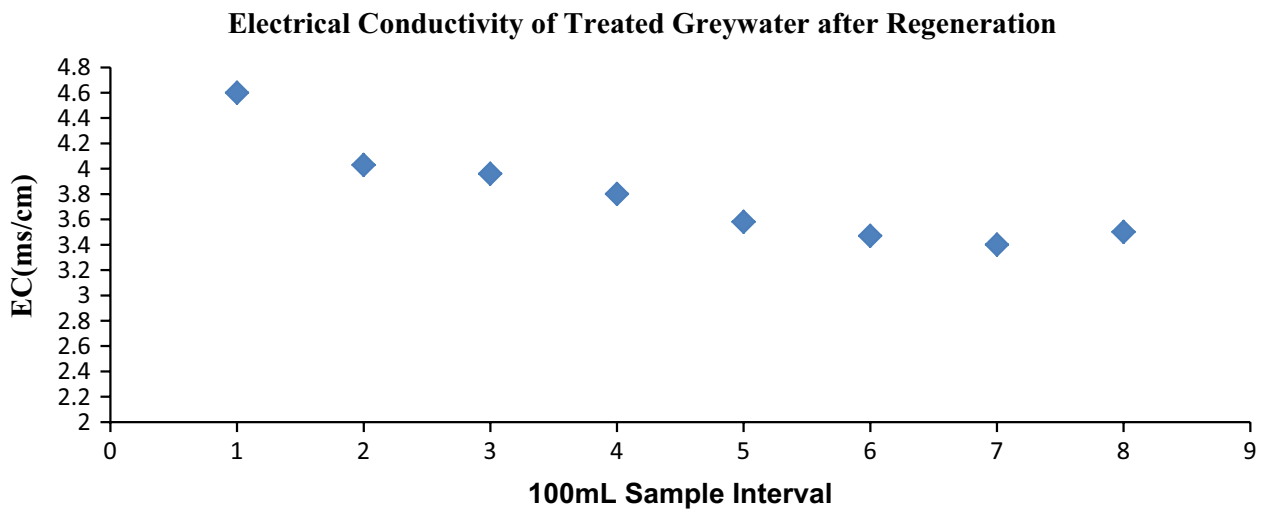


Table 6 Comparison of treated greywater quality with Kuwait group and Dammam aquifer literature (Sulami and Al Ruwaih 2004; Hadi and Al-Ruwaih 2005; Mukhopadhyay et al. 2012; Hadi et al. 2016)
Fig. 5 Graphical representation of comparison of treated greywater quality with Kuwait Group and Dammam aquifers

\begin{tabular}{|c|c|c|c|c|c|}
\hline S. no. & Parameter & Unit & $\begin{array}{l}\text { Dammam aqui- } \\
\text { fer avg. }\end{array}$ & $\begin{array}{l}\text { Kuwait group } \\
\text { aquifer avg. }\end{array}$ & $\begin{array}{l}\text { Treated } \\
\text { greywater } \\
\text { avg. }\end{array}$ \\
\hline 1. & EC & $\mu \mathrm{S} / \mathrm{cm}$ & 4555 & 14,192 & 2325 \\
\hline 2. & $\mathrm{pH}$ & - & 7.45 & 7.22 & 7.94 \\
\hline 3. & TDS & $\mathrm{mg} / \mathrm{L}$ & 3772 & 12,626 & 1508 \\
\hline 4. & $\mathrm{HCO}_{3}^{-}$ & $\mathrm{mg} / \mathrm{L}$ & 134 & 126 & 128 \\
\hline 5. & $\mathrm{Na}^{+}$ & $\mathrm{mg} / \mathrm{L}$ & 558 & 2460 & 330 \\
\hline 6. & $\mathrm{~K}^{+}$ & $\mathrm{mg} / \mathrm{L}$ & 21 & 147 & 6.5 \\
\hline 7. & $\mathrm{Ca}^{2+}$ & $\mathrm{mg} / \mathrm{L}$ & 419 & 716 & 147 \\
\hline 8. & $\mathrm{Mg}^{2+}$ & $\mathrm{mg} / \mathrm{L}$ & 144 & 267 & 14 \\
\hline 9. & $\mathrm{SO}_{4}^{2-}$ & $\mathrm{mg} / \mathrm{L}$ & 1338 & 1655 & 451 \\
\hline 10. & $\mathrm{Cl}^{-}$ & $\mathrm{mg} / \mathrm{L}$ & 934 & 4542 & 213 \\
\hline 11. & $\mathrm{~F}^{-}$ & $\mathrm{mg} / \mathrm{L}$ & $2.1^{\mathrm{a}}$ & - & 1.16 \\
\hline 12. & $\mathrm{NO}_{3}^{-}$ & $\mathrm{mg} / \mathrm{L}$ & 16 & 51 & 9.58 \\
\hline 13. & $\mathrm{~B}$ & $\mathrm{mg} / \mathrm{L}$ & $1.4^{\mathrm{a}}$ & - & 1.53 \\
\hline 14. & COD & $\mathrm{mg} / \mathrm{L}$ & $9.9^{\mathrm{a}}$ & $15^{\mathrm{a}}$ & 82.4 \\
\hline 15. & Total coliform & MPN/100 mL & $<1.0$ & $<1.0$ & $<1.0$ \\
\hline 16. & Fecal coliform & MPN/100 mL & $<1.0$ & $<1.0$ & $<1.0$ \\
\hline 17. & Escherichia coli & MPN/100 mL & $<1.0$ & $<1.0$ & $<1.0$ \\
\hline
\end{tabular}

${ }^{a}$ Fluoride, boron and COD values from the literature are available only for few samples of Dammam and Kuwait group aquifers

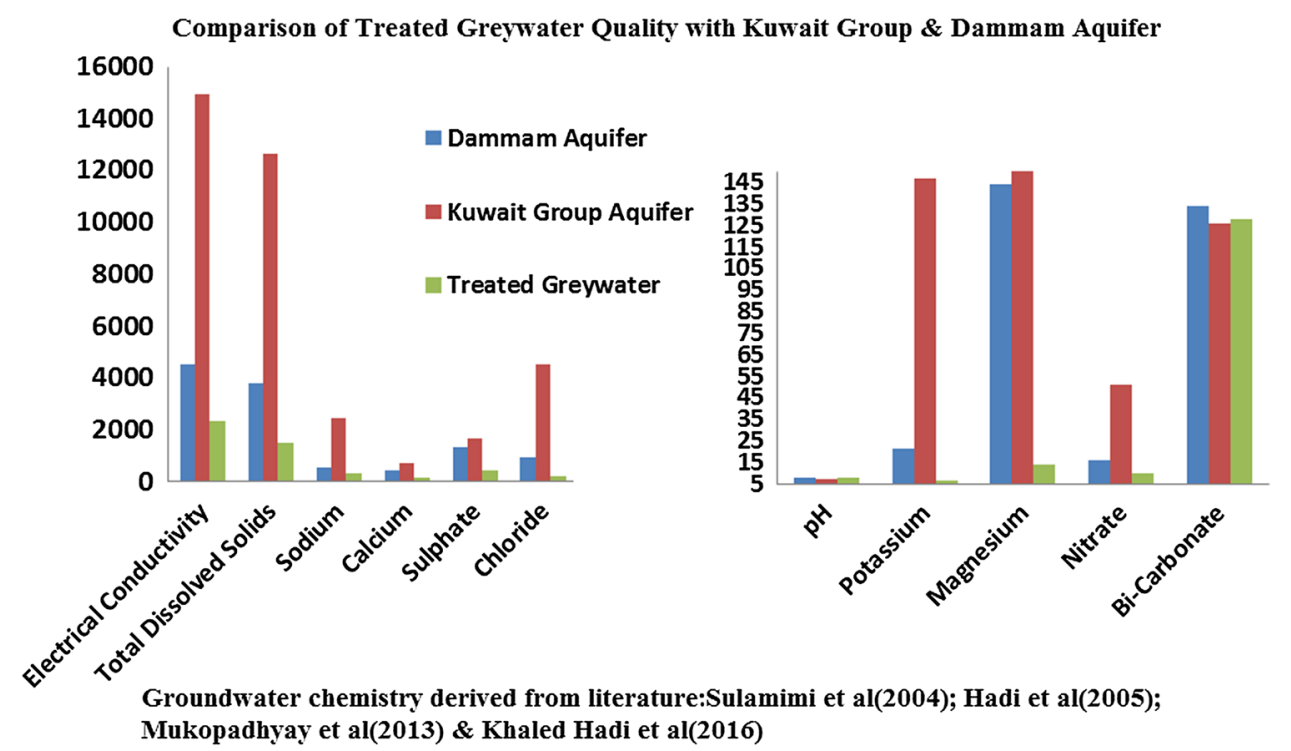

treated greywater was reduced to 7.94; however, the $\mathrm{pH}$ was higher than the groundwater of the aquifers, but falls within the WHO safety limits. The greywater treatment was inferred to be effective by this study, and it reports that certain metals were higher than the drinking water limits. Though the metals are above the potable limits, they are still below the limits prescribed for irrigation and domestic purposes. The study proved its efficiency equally to other existing methods, and the efficiency of reduction after treatment for some of the analyzed parameters was observed to be $23 \%, 95 \%$, $52 \%, 88 \%, 100 \% 100 \%$ for $\mathrm{pH}$, color, TDS, turbidity, total coliform, and $E$. coli, respectively.

The greywater thus produced is recommended for artificial recharge of groundwater as the ionic concentrations are comparatively lesser than the groundwater of both the aquifers. Further recharge or infiltration of the treated greywater into the aquifers will also have reduction of ion by a specific property like adsorption for the removal of these elements 
Fig. 6 Applications of treated greywater
Treated Greywater

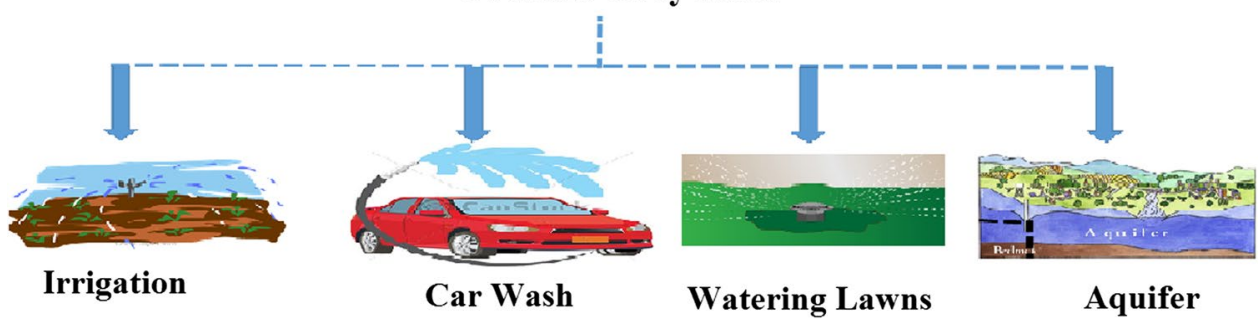

through ion exchange, selective adsorption, biosorption, etc., from the greywater. Though the method was successful in the laboratory, more extensive study in this line is being carried out by varying the size of the particles, the size of the column, the volume of the materials, the rate of flow, and change in the design of the column, but still this technique is unique for the greywater treatment in Kuwait. Also studies on greywater with higher EC ranges and varying organic compounds could throw more light upon the effectiveness of the study.

This study motivates a new outlook toward the large-scale benefit, i.e., the rate of water scarcity could be reduced, and sustains the water for future generations, since the available freshwater in Kuwait is very limited and considered as a strategic reserve. The treatment unit is user-friendly and can be installed in every house, and the treated greywater is suitable for car washing, irrigation, watering lawns, and, recharge of aquifers (Fig. 6). Finally, the study illustrates that the gravity-governed filtration is eco-friendly, economically viable and as effective as other existing expensive methods.

Acknowledgements The author acknowledges the Water Research Center, KISR, for the analysis and the support from the management of the Kuwait Institute for Scientific Research.

Open Access This article is distributed under the terms of the Creative Commons Attribution 4.0 International License (http://creativeco mmons.org/licenses/by/4.0/), which permits unrestricted use, distribution, and reproduction in any medium, provided you give appropriate credit to the original author(s) and the source, provide a link to the Creative Commons license, and indicate if changes were made.

\section{References}

Abedin SB, Rakib ZB (2013) Generation and quality analysis of greywater at Dhaka City. Environ Res Eng Manag 2(64):29-41. https ://doi.org/10.5755/j01.erem.64.2.3992

Abusam A (2008) Reuse of greywater in Kuwait. Int J Environ Stud 65:103-108. https://doi.org/10.1080/00207230701868204

Alaziz AIA, Al-Saqer NF (2014) The reuse of greywater recycling for high rise buildings in Kuwait Country. Int J Eng Res Appl 4(3):208-215

Al-Jarallah R (2013) The potential for reusing grey water and its generation rates for sustainable potable water security in Kuwait. J Eng Res 1:97-112
Al-Mashaqbeh OA, Ghrair AM, Megdal SB (2012) Grey water reuse for agricultural purposes in the Jordan Valley: household survey results in Deir Alla. Water 4:580-596. https://doi.org/10.3390/ w4030580

ASTM D6919-2017 (2017) Standard Test Method for Determination of dissolved alkali \& alkaline earth cations \& ammonium in water \& wastewater by Ion chromatography. https://doi.org/10.1520/d6919 $-17$

Bagundol TB, Awa AL, Enguito MRC (2013) Efficiency of slow sand filter in purifying well water. J Multidiscip Stud 2(1):86-102. https://doi.org/10.7828/jmds.v2i1.402

Bansal RC, Goyal M (2005) Activated Carbon Adsorption. CRC Press, Boca Raton

Barkouch Y, Fadeli SE, Flata K et al (2018) Removal efficiency of metallic trace elements by slow sand filtration: study of the effect of sand porosity and diameter column. Model Earth Syst Environ. https://doi.org/10.1007/s40808-018-0542-x

Beler-Baykal B (2015) Stream segregation in household use: a review of grey water as an alternative source of water and yellow water as an alternative source of fertilizers. Water Quality Exposure Health 7:27-37. https://doi.org/10.1007/s12403-013-0105-3

Chidambaram S, Ramanathan A, Vasudevan S (2003) Fluoride removal studies in water using natural materials: technical note. Water SA 29:339-344. https://doi.org/10.4314/wsa.v29i3.4936

Christova-Boal D, Eden RE, Mcfarlane S (1996) An investigation into greywater reuse for urban residential properties. Desalination 106:391-397. https://doi.org/10.1016/s0011-9164(96)00134-8

Edwin GA, Gopalsamy P, Muthu N (2013) Characterization of domestic gray water from a point source to determine the potential for urban residential reuse: a short review. Appl Water Sci 4:39-49. https://doi.org/10.1007/s13201-013-0128-8

EPA (2011) Water treatment manual: disinfection. Environmental Protection Agency, Johnstown Castle, Co., Wexford

Fernando A, Monteiro S, Pinto F, Mendes B (2009) Production of Biosorbents from waste olive cake and its adsorption characteristics for $\mathrm{Zn}^{2+}$ ion. Sustainability 1:277-297. https://doi. org/10.3390/su1020277

Finley S, Barrington S, Lyew D (2008) Reuse of domestic greywater for the irrigation of food crops. Water Air Soil Pollut 199:235245. https://doi.org/10.1007/s11270-008-9874-x

Friedler E (2004) Quality of individual domestic greywater streams and its implication for on-site treatment and reuse possibilities. Environ Technol 25:997-1008. https://doi.org/10.1080/09593 330.2004 .9619393

Ghaitidak DM, Yadav KD (2013) Characteristics and treatment of greywater-a review. Environ Sci Pollut Res 20:2795-2809. https ://doi.org/10.1007/s11356-013-1533-0

Ghoneim MM, El-Desoky HS, El-Moselhy KM et al (2014) Removal of cadmium from aqueous solution using marine green algae, Ulva Lactuca. Egypt J Aquat Res 40:235-242. https://doi.org/10.1016/j. ejar.2014.08.005

Gonzalez-Serrano E, Cordero T, Rodriguez-Mirasol J et al (2004) Removal of water pollutants with activated carbons prepared

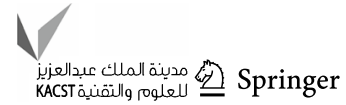


from $\mathrm{H}_{3} \mathrm{PO}_{4}$ activation of lignin from kraft black liquors. Water Res 38:3043-3050. https://doi.org/10.1016/j.watres.2004.04.048

Gross A, Kaplan D, Baker K (2007) Removal of chemical and microbiological contaminants from domestic greywater using a recycled vertical flow bioreactor (RVFB). Ecol Eng 31:107-114. https:// doi.org/10.1016/j.ecoleng.2007.06.006

Gual M, Moià A, March J (2008) Monitoring of an indoor pilot plant for osmosis rejection and greywater reuse to flush toilets in a hotel. Desalination 219:81-88. https://doi.org/10.1016/j.desal .2007.02.033

Hadi KM, Al-Ruwaih FM (2005) Impact of the environmental deposition on water: quality of the limestone aquifer, Kuwait. Emir J Eng Res 10(2):37-49

Hadi K, Kumar US, Al-Senafy M, Bhandary H (2016) Environmental isotope systematics of the groundwater system of southern Kuwait. Environ Earth Sci. https://doi.org/10.1007/s1266 5-016-5886-9

Huisman L, Wood WE (2005) An introduction to slow sand filtration. In: www.itacanet.org. Accessed 10 Oct 2018

Juan Y-K, Chen Y, Lin J-M (2016) Greywater reuse system design and economic analysis for residential buildings in taiwan. Water 8:546. https://doi.org/10.3390/w8110546

Kariuki FW (2011) The potential of a low-cost technology for the greywater treatment. Open Environ Eng J 4:32-39. https://doi. org/10.2174/1874829501104010032

Katukiza AY, Ronteltap M, Niwagaba CB et al (2014) Grey water characterization and pollutant loads in an urban slum. Int J Environ Sci Technol 12:423-436. https://doi.org/10.1007/s13762-013-0451-5

KEPA Guidelines for potable water (2017) In: Kuwaitalyawm. Issue No. 1355. https://kuwaitalyawm.media.gov.kw/. Accessed 22 Mar 2019

Khalaphallah R (2012) Greywater treatment for reuse by slow sand filtration: study of pathogenic microorganisms and phage survival. Chemical and Process Engineering. Ecole des Mines de Nantes, English. <NNT: 2012EMNA0051>

Leas EC, Dare A, Al-Delaimy WK (2013) Is gray water the key to unlocking water for resource-poor areas of the middle east, North Africa, and other arid regions of the world? Ambio 43:707-717. https://doi.org/10.1007/s13280-013-0462-y

Lechevallier MW, Au K-K (2004) Water treatment and pathogen control: process efficiency in achieving safe drinking-water (Who Drinking Water Quality)

Memon FA, Zheng Z, Butler D et al (2007) Life cycle impact assessment of greywater recycling technologies for new developments. Environ Monit Assess 129:27-35. https://doi.org/10.1007/s1066 1-006-9422-3

Mohamed RMSR, Kassim AHM, Anda M, Dallas S (2013) A monitoring of environmental effects from household greywater reuse for garden irrigation. Environ Monit Assess 185:8473-8488. https:// doi.org/10.1007/s10661-013-3189-0

Mohan D, Chander S (2001) Single component and multi-component adsorption of metal ions by activated carbons. Colloids Surf A Physicochem Eng Asp 177:183-196. https://doi.org/10.1016/ s0927-7757(00)00670-1

Mourad KA, Berndtsson JC, Berndtsson R (2011) Potential fresh water saving using greywater in toilet flushing in Syria. J Environ Manag 92:2447-2453. https://doi.org/10.1016/j.jenvman.2011.05.004

Mukhopadhyay A, Al-Haddad A, Kotwicki V et al (2012) Feasibility of artificial recharge at the Az-Zaqlah depression in Kuwait. Groundw Model Manag Uncertain. https://doi.org/10.1201/b1316 7-25

MWRI-GOSS (2009) Technical Guidelines for the Construction and Management of Slow Sand Filters. A Manual for Field Staff and Practitioners

Nam S-W, Choi D-J, Kim S-K et al (2014) Adsorption characteristics of selected hydrophilic and hydrophobic micropollutants in water using activated carbon. J Hazard Mater 270:144-152. https://doi. org/10.1016/j.jhazmat.2014.01.037

Nowicki H, Nowicki G (2016) The basics of activated carbon adsorption water technology in the basics of activated carbon adsorption. https://www.watertechonline.com. Accessed 20 Mar 2019

Packialakshmi S, Balaji S, Kumaresan T (2015) Inducing recharge of groundwater by treated waste water-a pilot study in Southern Chennai Metropolitan Area. Indian J Sci Technol 8(11):1-17. https://doi.org/10.17485/ijst/2015/v8i11/71806

Prasad G et al (2006) Sand intermittent filtration technology for safer domestic sewage treatment. J Appl Sci Environ Manag. https:// doi.org/10.4314/jasem.v10i1.17308

Redwood M, Bouraoui M, Houmane B (2013) Rainwater and greywater harvesting for urban food security in La Soukra, Tunisia. Int J Water Resour Dev 30:293-307. https://doi.org/10.1080/07900 627.2013.837367

Revitt DM, Eriksson E, Donner E (2011) The implications of household greywater treatment and reuse for municipal wastewater flows and micropollutant loads. Water Res 45:1549-1560. https ://doi.org/10.1016/j.watres.2010.11.027

Rice EW (2017) Standard methods for the examination of water and wastewater, 23rd edn. American Public Health Association, Washington

Saad F, Jamil M, Odli Z, Izhar T (2016) Study on modified sand filtration towards water quality of wet market waste water. MATEC Web Conf 78:01104. https://doi.org/10.1051/matecconf/20167 801104

Saroj BP, Sane Mukhund G (2011) Performance of greywater treatment plant by the economical way for Indian rural development. Int $\mathbf{J}$ Chem Tech Res 3(4):1808-1815

Silva FD (2000) In: Activated carbon filtration. http://www.watertreat mentguide.com/activated_carbon_filtration.htm. Accessed 8 May 2019

Statistical Year Book (Water), Kuwait (2016) 41(B) edn. Ministry Of Electricity \& Water

Sulami JS, Al Ruwaih FM (2004) Geological, structural and geochemical aspects of the main aquifer systems in Kuwait. Kuwait J Sci Eng 31:149-174

Surendran S, Wheatley AD (1998) Grey-water reclamation for non-potable re-use. Water Environ J 12:406-413. https://doi. org/10.1111/j.1747-6593.1998.tb00209.x

Terry C (2018) The disadvantages of desalination. In: Sciencing. https ://sciencing.com/disadvantages-desalination-5961767.html. Accessed 09 Feb 2018

U.S. EPA (1994) Method 200.7: determination of metals and trace elements in water and wastes by inductively coupled plasma-atomic emission spectrometry. Revision 4.4. Cincinnati, OH

Verma S, Daverey A, Sharma A (2017) Slow sand filtration for water and wastewater treatment - a review. Environ Technol Rev 6:4758. https://doi.org/10.1080/21622515.2016.1278278

WHO (2006) A compendium of standards for wastewater reuse in the Eastern Mediterranean Region- apps.who.int. http://apps.who.int/ iris/bitstream/handle/10665/116515/dsa1184.pdf; sequence $=1$. Accessed 7 Mar 2019

Yogafanny E et al (2014) Study of slow sand filtration in removing total coliforms and E. Coli. Jurnal Sains \& Teknologi Lingkungan 6(2):107-116. https://doi.org/10.20885/jstl.vol6.iss2.art4

Zhang Y, Grant A, Sharma A et al (2009) Alternative water resources for rural residential development in Western Australia. Water Resour Manag 24:25-36. https://doi.org/10.1007/s 1126 9-009-9435-0

Publisher's Note Springer Nature remains neutral with regard to jurisdictional claims in published maps and institutional affiliations. 